\title{
Mediating Role of Academic Procrastination between Emotional Intelligence and Academic Performance of Pakistani Youth
}

\author{
Aqsa Wasim ${ }^{1}$, Muhammad Adeeb ${ }^{2}$, Mubeen Mateen ${ }^{1}$
}

\section{Abstract}

The purpose of this research was to measure the mediating role of academic procrastination between emotional intelligence and academic performance in Pakistani youth. In total, 347 youth were selected using multi-stage random sampling from three major cities of Punjab province in Pakistan (Rawalpindi, Lahore, \& Faisalabad). The average age remained [M (22.70+3.43)]. Two instruments were used; The Schutte Self Report Emotional Intelligence Test and Yockey Academic Procrastination Scale Short Form, while academic performance was calculated considering semester grade point average (SGPA). The results showed that emotional intelligence was significant positively correlated with academic performance. In mediation, Process Macro Hayes (2018) approach was used. The results showed that academic procrastination endured significant negative mediator in relationship of emotional intelligence and academic performance. The female youth were significantly higher in academic performance and emotional intelligence as compared to male youth, while male youth were significantly higher in academic procrastination. Emotional intelligence increases the academic performance and reduces academic procrastination among university students, while academic procrastination endured negative mediator between emotional intelligence and academic procrastination. Males have more prone towards academic procrastination and reported lower emotional intelligence and academic performance as compared to females. The limitations and future avenues were also discussed.

Keywords: Academic Performance; Academic Procrastination; Emotional Intelligence; Mediation; Pakistan; Youth

Received: 19 March 2021; Revised Received: 29 June 2021; Accepted: 14 July 2021

${ }^{1}$ Research Scholar, Dept of Psychology, Riphah International University, Faisalabad.

${ }^{2} \mathrm{PhD}$ Candidate, Awang Had Salleh Graduate School of Arts \& Sciences (AHSGS), Universiti Utara Malaysia.

\section{Corresponding Author Email:}

aksawasim11@gmail.com

\section{Introduction}

Emotional intelligence (EI) is the capacity of emotional information to be perceived, integrated, communicated and controlled (Brackett et al., 2006). Further, EI defines capacity, skill or ability to evaluate, find out, and manage the emotions of people (Mayer \& Salovey, 1995). Further, Mayer et al.
(2012) detailed five components of emotional intelligence; a) Self-awareness b) Motivating self c) Managing emotions d) Interpersonal skills and e) Empathy. According to Lopes et al. (2005), Emotional intelligence is a skill to reason about emotions as well as the capacity of using them to improve thinking processes. Deniz et al. (2009) described the negative association of emotional intelligence with academic procrastination.

Mostly university settings require the efficient performance and successful completion of challenging assignments within specified time. Approximately 10$20 \%$ of students complete work well in time, while others procrastinate, they wait for the last minute (Steel, 2007). In many researches, the negative correlation has been seen between the procrastination and exam grades

This article is distributed under the terms of the Creative Commons Attribution Non Commercial 4.0 License (http://www.creativecommons.org/licenses/by-nc/4.0/) which permits nonCommercial use, reproduction and distribution of the work without further permission provided the original work is attributed as specified. 
as well as marks (Tice \& Baumeister, 1997; Doherty, 2006).

Milgram et al. (1998) defined academic procrastination as a trait or behavioral temperament to delay or postpone a task or decision making. Later, Schraw and colleagues (2007) defined as unneeded postponement or avoidance of academic work that is to be completed in time. Further academic procrastination is predictor of academic performance (Howell \& Watson, 2007). Kim and Seo (2015) found inverse relationship of academic procrastination with academic performance. Many studies took grade point average (GPA) as a measure to calculate academic performance (Conard, 2006; Khan et al., 2012; Saleem et al., 2016). Further, the academic performance of students is influenced through emotions. It has been suggested by a recent era of modern educational psychology that educational qualifications are sensitive to sentiments (Artino et al., 2010).

The emotions may be linked to university achievement as described by Boyatzis (2006). The emotional intelligence as a predictive factor of success was endorsed by Duran et al. (2006). However, Dhull, (2013) explained that a student must consider their natural passions and emotions. SánchezÁlvarez, Martos, and Extremera, (2020) reported in meta-analysis that significant positive relationship exists between emotional intelligence and academic performance in secondary school students. There is sufficient evidence to recommend that EI has a positive association with academic performance (MacCann et al., 2020; Richardson et al., 2012).

Further, Deniz et al. (2009) described that the academic procrastination and emotional intelligence are correlated negatively. In a study concluded by Mccloskey (2012), it was found that academic procrastination is a significant mediator between conscientiousness and academic performance. Whereas a recent study reported that academic procrastination found significant mediator in relationship of school attachment and life satisfaction (Çıkrıkçı \& Erzen, 2020).

In Pakistani context, Khan et al. (2014) reported that in academic procrastination, the gender plays the role of difference which is significant and males are more procrastinator than females, while in Turkish students, results also showed similar trends and concluded that males were higher than females in terms of academic procrastination (Özer et al., 2009). In many other studies, significant gender disparities have also been identified and males reported more academic procrastination then females (Balkis \& Erdinç, 2017).

Chaudhry et al. (2013) taken into account that whether female students of Pakistan were emotionally more intellectual than male students of Pakistan. Moreover, many other studies concluded that females were higher in emotional intelligence than males (Luebbers et al., 2007; Lyusin, 2006; McIntyre, 2010). Evidence suggests that gender differences in academic performance showed that females were higher in academic performance than males (Chew et al., 2013; Fayombo, 2010; Parajuli \& Thapa, 2017). Likewise, Cheeseman et al. (2006) also confirmed that female students were more likely than male students to receive honors degrees in the university.

The literature provides direct relationship of emotional intelligence with academic performance but indirect relationship is missing in context of academic procrastination. Thus, the goal of the current research is to measure the mediating role of academic procrastination between emotional intelligence and academic performance of Pakistani youth. Further, this study aimed to find out the gender difference in terms of emotional intelligence, academic procrastination and academic performance. 
The above cited scenario provides a sufficient evidence to consider and it needs to be extended, so following hypotheses are devised.

\section{Hypotheses of the Study}

1. There would be a positive relationship between emotional intelligence and academic performance.

\section{Method}

\section{Sample}

In total, 347 youth were selected from three major cities of Punjab province in Pakistan (Rawalpindi, Lahore, \& Faisalabad). Both gender was selected in this research $($ Male = 172 and Female = 175). Age, gender, education, and family system were included in demographic variables. The data were collected physically during the period of October and November 2020, during this period institutes were opened. The sample calculated through online calculator A-priori statistics "multiple regression" (Soper, 2020); power and precision were (0.9\%) and the confidence interval was $(.95 \%)$. Furthermore, cross-sectional research design was used in this research. The data were collected using multi-stage random sampling. The simple random sampling is not possible with large sample framework, therefore, multistage random sampling was considered in this research to reach the true sample. Sedgwick (2015) preferred multistage sampling to simple random sampling when the population is geographically diverse.

\section{Inclusion and Exclusion Criteria}

Both male and female regular university students with the minimum class attendance $60 \%$ were included in this research from the selected public sector universities. The age range were considered 18-30 years and only BS (Hons) and MS/MPhil students were included in this research. Whereas, individuals with psychological problems and
2. Academic procrastination would be a significant mediator in relationship of emotional intelligence and academic performance.

3. There would be a significant variance of emotional intelligence, academic procrastination, and academic performance between male and female youth.

any physical disease or disability were excluded from research.

\section{Instruments}

Schutte Self Report Emotional Intelligence Test (SSEIT-33)

Schutte et al. (1998) developed this scale to measure the self-reporting of trait emotional intelligence. This is 33 items test with five point Likert scale that measure response with strongly agree to strongly disagree. Schutte et al. (1998) tested the reliability rating of 0.90 for SSEIT-33.

Yockey Academic Procrastination Scale Short Form (APS-S-5)

Yockey (2016) developed APS-S-5 that have 5 items Likert scale with response on totally disagree and totally agree. The higher scores representing a high propensity of procrastination. The reliability was good (Cronbach's alpha $=.87$ ).

\section{Academic Performance}

Academic performance was calculated by semester grade point average (SGPA). The same method is used by past researches e.g. Saleem et al. (2016).

\section{Statistical Analysis}

After the data collection, analysis was done using SPSS (23.0). The analysis of bivariate correlation and independent sample t-test were considered to test the hypotheses. While, in analysis of mediation, an approach of Process Macro Hayes (2018) was applied. 


\section{Ethical Considerations}

Following the ethical considerations in quantitative survey research, the compulsory ethical considerations were addressed (e.g. formal permission from the actual authors of scales, informed consent, anonymity and confidentiality). Whereas, before conducting research, a formal permission was also obtained from the committee of ethical review.

\section{Results}

\section{Table 1}

Frequency Distribution of Demographic Variables $(N=347)$

\begin{tabular}{lllll}
\hline Respondent's Characteristics & $\boldsymbol{f}$ & $\boldsymbol{\%}$ & $\boldsymbol{M}(\boldsymbol{S D})$ \\
\hline Age & & & & $22.70(3.43)$ \\
Gender & Male & 172 & 49.6 & \\
\multirow{2}{*}{ Education } & Female & 175 & 50.4 & \\
& B.S (Hons) & 299 & 86.2 & \\
Family System & MS/MPhil & 48 & 13.8 & \\
& Nuclear Family & 226 & 65.1 & \\
\multirow{2}{*}{ Institute } & Joint Family & 121 & 34.9 & \\
& Rawalpindi & 112 & 32.3 & \\
& Lahore & 107 & 30.8 & \\
\hline
\end{tabular}

In Table 1, the results reveal the frequency distribution of the demographic variables. The average age of respondents was $(\mathrm{M}=$ $22.70, \mathrm{SD}=3.43)$. In gender, $172(49.6 \%)$ were male and $175(50.4 \%)$ were female participants. In education levels, 299(86.2\%) students were enrolled in BS (Hons) level of education and $48(13.8 \%)$ students were enrolled MS/MPhil level of education. For family system, 226(65.1\%) respondents were from nuclear family system and 121(34.9\%) respondents were from joint family system. Whereas, $112(32.3 \%)$ respondents were from public sector university of Rawalpindi, $107(30.8 \%)$ respondents were from public sector university of Lahore and 128(32.3\%) respondents were from public sector university of Faisalabad.

Table 2

Bivariate Correlation among Emotional Intelligence, Academic Procrastination., and Academic Performance $(N=347)$

\begin{tabular}{llllll}
\hline Variables & M & SD & $\begin{array}{l}\text { Emotional } \\
\text { Intelligence }\end{array}$ & $\begin{array}{l}\text { Academic } \\
\text { Procrastination }\end{array}$ & $\begin{array}{l}\text { Academic } \\
\text { Performance }\end{array}$ \\
\hline Emotional Intelligence & 104.71 & 17.91 & - & $-.38^{* * *}$ & $.41^{* * *}$ \\
Academic & 16.39 & 4.03 & & - & $-.53^{* * *}$ \\
Procrastination & & & & & - \\
Academic Performance & 3.18 & 0.38 & & & - \\
\hline${ }_{* * * *}<<.001$ & & & & &
\end{tabular}

Bivariate Pearson correlation showed in Table 2 significant negative association between emotional intelligence and academic procrastination $(\mathrm{r}=-.38, p<.001)$. Further, 
results revealed that emotional intelligence was significantly positively correlated $(\mathrm{r}=$ $.41, p<.001)$ with academic performance, while academic procrastination was highly significantly negatively associated $(\mathrm{r}=-.53$, $p<.0001)$ with academic performance.

Table 3

Procrastination as Mediator in relationship between Emotional Intelligence and Academic Performance of Youth $(N=347)$

\begin{tabular}{llll}
\hline & \multicolumn{2}{c}{ Academic Performance } \\
\cline { 2 - 4 } Predictors & Model 1 $B$ & $\boldsymbol{B}$ & $\mathbf{9 5 \%} \boldsymbol{C I}$ \\
\cline { 2 - 4 } Constant & $18.72^{* *}$ & $21.1 *^{* * *}$ & {$[15.54,22.93]$} \\
Emotional Intelligence & $.39^{* *}$ & $.42^{* *}$ & {$[.33, .58]$} \\
Academic Procrastination & & $-.52^{* *}$ & {$[-.16, .03]$} \\
$\mathrm{R}^{2}$ & .19 & .23 & \\
$\mathrm{~F}$ & $45.22^{* *}$ & $49.56^{* *}$ & \\
$\Delta \mathrm{R}^{2}$ & & .26 & \\
$\Delta \mathrm{F}$ & & $52.88^{* *}$ & \\
\hline
\end{tabular}

${ }^{* *} p<.01$

Note. $\mathrm{B}=$ Unstandardized regression coefficient, $\mathrm{CI}=$ Confidence interval

The results showed in Table 3 that academic procrastination endured significant negative mediator between emotional intelligence and academic performance. While, emotional intelligence is significant direct and indirect predictor of academic performance.

\section{Table 4}

t-test use for differences between Male and Female Youth for Emotional Intelligence, Academic Procrastination, and Academic Performance $(N=347)$

\begin{tabular}{|c|c|c|c|c|c|c|c|c|}
\hline \multirow[t]{2}{*}{ Variables } & \multicolumn{2}{|c|}{$\operatorname{Male}(n=172)$} & \multicolumn{2}{|c|}{$\begin{array}{l}\text { Female }(n \\
\text { 175) }\end{array}$} & \multirow[t]{2}{*}{$=\mathbf{t}$} & \multicolumn{3}{|c|}{$95 \% \mathrm{CI}$} \\
\hline & M & SD & M & SD & & LL & UL & $\begin{array}{l}\text { Cohen's } \\
\text { d }\end{array}$ \\
\hline Emotional Intelligence & 99.10 & 13.33 & 113.26 & 9.28 & $-\overline{-}^{*} .07^{* * *}$ & $\begin{array}{l}- \\
17.07\end{array}$ & -5.40 & -1.23 \\
\hline $\begin{array}{l}\text { Academic } \\
\text { Procrastination }\end{array}$ & 19.03 & 3.81 & 13.69 & 4.92 & $5.78^{* * *}$ & 1.33 & 7.35 & 1.21 \\
\hline Academic Performance & 3.02 & .31 & 3.33 & 0.29 & $-.29^{*}$ & -.79 & .12 & -1.03 \\
\hline
\end{tabular}
${ }^{*} p<.05,{ }^{* * * *} p<.001$

Note. $\mathrm{CI}=$ confidence interval, $\mathrm{LL}=$ lower limit, $\mathrm{UL}=$ upper limit

In gender differences, the results showed in Table 4 that males youth were significantly higher in academic procrastination $(\mathrm{t}=5.78, p$ $<.001)$ than female youth, while the females were significantly higher in emotional intelligence $(\mathrm{t}=-8.07, p<.001)$ and academic performance $(\mathrm{t}=-29, p<.05)$ as compared to males. 


\section{Discussion}

The overarching aim of present research is to measure the mediating role of academic procrastination between emotional intelligence and academic performance of Pakistani youth. A plethora of studies available in Western context, but very few are available in Pakistan. For this purpose, contemporary study is planned to bridge the very gap. In the current study, the testing of $\mathrm{H}_{1}$, showed that emotional intelligence was significantly positively correlated $(\mathrm{r}=.41, p$ $<.001)$ with academic performance. Many studies in past concluded that high emotional intelligence make youth perform better in academics as compared to low emotional intelligence in youth (Chew et al., 2013; Dulewicz \& Higgs, 2000; MacCann et al., 2020). In a past study Sergio (2001) found emotional intelligence is a vital indicator of academic performance among students. Hence, the results of present study $\left(\mathrm{H}_{1}\right)$ are in-line with the existing literature.

Further, results for $\mathrm{H}_{2}$ revealed that academic procrastination endured significant negative mediator between emotional intelligence and academic performance. A past study found that emotional intelligence was significant negative predictor of academic procrastination, while emotional intelligence was significant positive predictor of academic performance (Hen \& Goroshit, 2014). Another study, Deniz et al. (2009) found emotional intelligence negatively predicted academic procrastination. Furthermore, studies concluded that the ability to utilize and regulate emotions has been revealed positively associated with academic performance (Boyatzis, 2006; Daus \& Ashkanasy, 2005).

The $\mathrm{H}_{3}$ results revealed that male youth were significantly higher in academic procrastination $(\mathrm{t}=5.78, p<.001)$ than female youth, while the females were significantly higher in emotional intelligence $(\mathrm{t}=-8.07, p$ $<.001)$ and academic performance $(\mathrm{t}=-29, p$
<.05) as compared to males. Literature support that male youth have higher tendency to procrastinate than females' youth (Özer et al., 2009). While many other studies concluded that gender played a significant role of difference in academic procrastination, moreover, males were higher in academic procrastination as compared to females (Pychyl et al., 2002). Additionally, a study concluded that emotional intelligence was higher in Pakistani female youth as compared to Pakistani male youth. Many others studies showed that females were higher in emotional intelligence than males (Luebbers et al., 2007; Lyusin, 2006; McIntyre, 2010). In academic performance, past studies showed that females were performed bitterly in academic performance than males (Fayombo, 2010, Kutnick, 2000). The reason behind the males being low average outcomes in academic is delaying behavior.

\section{Conclusion}

Emotional intelligence increases the academic performance and reduces academic procrastination among university students, while academic procrastination endured negative mediator between emotional intelligence and academic procrastination. Further in gender, males are more prone towards academic procrastination and report lower level of emotional intelligence and academic performance as compared to females.

\section{Limitations of the Study}

The data were collected only form public sector universities that have limited generalizability. So, it is suggested to future researches, comparative study should be conducted with university students from public sector and private sectors. In this research, only BS (Hons) and MS/MPhil students were selected, so in the future, PhD 
students should also be included. Quantitative research type was used in this research, so in future, qualitative researchers should be conducted to explore the more findings and factors related with academic performance and academic procrastination.

\section{References}

Artino, A. R., La Rochelle, J. S., \& Durning, S. J. (2010). Second-year medical students' motivational beliefs, emotions, and achievement. Medical education, 44(12), 1203-1212.

Balkis, M., \& Erdinç, D. U. R. U. (2017). Gender differences in the relationship between academic procrastination, satifaction with academic life and academic performance. Electronic Journal of Research in Educational Psychology, 15(1), 105-125.

Boyatzis, R., (2006). Using tipping points of emotional intelligence and cognitive competencies to predict financial performance of leaders. Psicothema, 18(1), 124-131.

Brackett, M.A., Rivers, S.E., Shiffman, S., Lerner, N., \& Salovey, P., (2006). Relating emotional abilities to social functioning: A comparison of selfreport and performance measures of emotional intelligence. Journal of Personality and Social Psychology, 91(4), 780-795.

Chaudhry, A. A., Jan, F. A., Sajjad, M., \& Ali, S. (2013). Emotional Intelligence and Students: A Pakistani Perspective. World Applied Sciences Journal, 22(3), 319-325.

Cheeseman, J., Simpson, N., \& Wint, A.G. (2006). Determinants of Student Performance at the University: Reflections from the Caribbean. Research project of uwi, Mona,

\section{Implications of the Study}

This research will be helpful for scholars, psychologists, educational psychologists, educationists, students, parents and government agencies for policy making. Psychologist should conduct seminars among university students to enhance their emotional intelligence and reduce academic procrastination.

strategic Transformation Team. Retrieved on July 2011 [Online] Available:

http://www.mona.uwi.edu/opair/rese arch/student-performance-paperrevised.pdf

Chew, B. H., Zain, A. M., \& Hassan, F. (2013). Emotional intelligence and academic performance in first and final year medical students: a crosssectional study. BMC medical education, 13(1), 1-10.

Çıkrıkçı, Ö., \& Erzen, E. (2020). Academic procrastination, school attachment, and life satisfaction: a mediation model. Journal of Rational-Emotive \& Cognitive-Behavior Therapy, 38(1) 225-242.

Conard, M.A. (2006). Aptitude is not enough: How personality and behavior predict academic performance. Journal of Research in Personality, 40(3), 339-346.

Daus, C. S., \& Ashkanasy, N. M. (2005). The case for the ability-based model of emotional intelligence in organizational behavior. Journal of Organizational behavior, 26(4), 453466.

Deniz, M., Tras, Z., \& Aydogan, D. (2009). An Investigation of Academic Procrastination, Locus of Control, and Emotional Intelligence. Educational Sciences: Theory and Practice, 9(2), 623-632. 
Dhull P. (2013) Emotional Intelligence of Students in Relation to Their Academic Achievements. International Indexed \& Refereed Research Journal, 4, 51-52.

Doherty, W. (2006). An analysis of multiple factors affecting retention in Webbased community college courses. The Internet and Higher Education, 9(4), 245-255.

Dulewicz, V., \& Higgs, M. (2000). Emotional intelligence-A review and evaluation study. Journal of managerial Psychology, 15(4), 341372.

Durán, A., $\quad$ Extremera, N., Rey, L., Fernández-Berrocal, P., \& Montalbán, F. M. (2006). Predicting academic burnout and engagement in educational settings: Assessing the incremental validity of perceived emotional intelligence beyond perceived stress and general selfefficacy. Psicothema, 18, 158-164.

Fayombo, G. A. (2010). Gender differences in study habit, interest in schooling and attitude towards substance abuse among secondary school adolescents in Barbados. Caribbean Education Research Journal, 2(1), 87-95.

Hayes, A. F. (2018). Introduction to mediation, moderation, and conditional process analysis: $A$ regression-based approach (2nd edition). New York: The Guilford Press.

Hen, M., \& Goroshit, M. (2014). Academic Procrastination, Emotional Intelligence, Academic Self-Efficacy, and GPA A Comparison Between Students With and Without Learning Disabilities. Journal of learning disabilities, 47(2), 116-124.

Howell, A.J., \& Watson, D.C., (2007). Procrastination: Associations with achievement goal orientation and learning strategies. Personality and Individual Differences, 43(1), 167178.

Khan, A. A., Saleem, M., Tahir, M. A., \& Nadeem, M. (2012). Emotional Intelligence and Self-Esteem as Predictors of Academic Success among Higher Education Students: A Survey Conducted at the Islamia University of Bahawalpur, Pakistan. Journal of Educational Research, 15(1), 56.

Khan, M. J., Arif, H., Noor, S. S., \& Muneer, S. (2014). Academic procrastination among male and female university and college students. FWU Journal of Social Sciences, 8(2), 65-70.

Kim, K. R., \& Seo, E. H. (2015). The relationship between procrastination and academic performance: A metaanalysis. Personality and Individual Differences, 82(8), 26-33.

Kutnick, P. (2000). Girls, boys and school achievement: Critical comments on who achieves in schools and under what economic and social conditions achievement takes place-a Caribbean perspective1. International Journal of Educational Development, 20(1), 65-84.

Lopes, P.N., Salovey, P., Côte, S., \& Beers, M., (2005). Emotion regulation abilities and the quality of social interaction. Emotion, 5(1), 113-118.

Luebbers, S., Downey, L. A., \& Stough, C. (2007). The development of an adolescent measure of EI. Personality and Individual Differences, 42(6), 999-1009.

Lyusin, D. B. (2006). Emotional intelligence as a mixed construct: Its relation to personality and gender. Journal of Russian \& East European Psychology, 44(6), 54-68.

MacCann, C., Jiang, Y., Brown, L. E., Double, K. S., Bucich, M., \& 
Minbashian, A. (2020). Emotional intelligence predicts academic performance: A metaanalysis. Psychological Bulletin, 146 (2), 150-186.

Mayer, J. D., \& Salovey, P. (1995). Emotional intelligence and construction and regulation of feelings. Applied and Preventive Psychology, 4(3), 197-208.

Mayer, J. D., Salovey, P., \& Caruso, D. R. (2012).. What is Emotional intelligence? $J$ sport psychology [serial online] 63(6), 503-7.

McCloskey, J. (2012). Finally, my thesis on academic procrastination. https://rc.library.uta.edu/utair/handle/10106/9538

McIntyre, H. H. (2010). Gender differences in the nature and linkage of higherorder personality factors to trait and ability emotional intelligence. Personality and Individual Differences, 48(5), 617622.

Milgram, N., Mey-tal, G., \& Levison, Y., (1998). Procrastination, generalized or specific, in college students and their parents. Personality and Individual Differences, 25(2), 297316.

Özer, B. U., Demir, A., \& Ferrari, J. R. (2009). Exploring academic procrastination among Turkish students: Possible gender differences in prevalence and reasons. The Journal of social psychology, 149(2), 241-257.

Parajuli, M., \& Thapa, A. (2017). Gender Differences in the Academic Performance of Students. Journal of Development and Social Engineering, 3(1), 39-47.

Pychyl, T. A., Coplan, R. J., \& Reid, P. A. (2002). Parenting and procrastination: gender differences in the relations between procrastination, parenting style and self-worth in early adolescence. Personality and Individual Differences, 33(2), 271285.

Richardson, M., Abraham, C., \& Bond, R. (2012). Psychological correlates of university students' academic performance: a systematic review and meta-analysis. Psychological bulletin, 138(2), 353-387.

Saleem, M., Adeeb, M., Khan, M., Zaffar M, \& Tufail, M. W., (2016) Impact of Terrorism on Academic Outcomes among Higher Learning Students of Punjab, Pakistan. $15^{\text {th }}$ annual Conference of Pakistan Psychological Association, University of Peshawar Bara Gali.

Sánchez-Álvarez, N., Martos, M. P. B., \& Extremera, N. (2020). A metaanalysis of the relationship between emotional intelligence and academic performance in secondary education: A multi-stream comparison. Frontiers in Psychology, 11. https://doi.org/10.3389/fpsyg.2020.0 1517

Schraw, G., Wadkins, T., \& Olafson, L., (2007). Doing the things we do: A grounded theory of academic procrastination. Journal of Educational Psychology, 99(1), 1225.

Schutte, N.S., Malouff, J.M., Hall, L.E., Haggerty, D.J., Cooper, J.T., Golden, C. J., \& Dornheim, L., (1998). Development and validation of a measure of emotional intelligence. Personality and Individual Differences, 25, 167-177.

Sedgwick, P. (2015). Multistage sampling. BMJ (Clinical research ed.), 351, h4155. https://doi.org/10.1136/bmj.h4155 
Sergio, R. P. (2001). Emotional intelligence and mental ability as determinants of job performance among plant supervisors in selected manufacturing firms. Unpublished Master's Thesis, De La Salle University, Behavioral Sciences Department, Philippines.

Soper, D.S. (2020). A-priori Sample Size Calculator for Multiple Regression [Software]. Available from https://www.danielsoper.com/statcal

c

Steel, P., (2007). The nature of procrastination: A meta-analytic and theoretical review of quintessential self-regulatory failure. Psychological Bulletin, 133(1),65-94.

Tice, D. M., \& Baumeister, R. F. (1997). Longitudinal study of procrastination, performance, stress, and health: The costs and benefits of dawdling. Psychological Science, 8(6), 454-458.

Yockey, R. D. (2016). Validation of the Short Form of the Academic Procrastination Scale. Psychological Reports, 118(1), 171-179. https://doi.org/10.1177/00332941156 26825 